\title{
Morphological features of the tongue in the quail (Coturnix coturnix japonica)
}

\author{
POURLIS, A. F.* \\ DVM, PhD, Laboratory of Anatomy, Histology \& Embryology, Faculty of Veterinary Medicine, \\ University of Thessaly, Karditsa, GR 43100, Greece \\ ${ }^{*}$ E-mail: apourlis@vet.uth.gr
}

\begin{abstract}
Introduction: The aim of the study was to examine the morphology of the tongue in the quail. Materials and Methods: For this purpose, the tongues of six adult quails (three males, three females) were studied. Specimen's observation was performed with a scanning electron microscope. Results: The tongue was triangular in shape with a shallow median groove along the body. The length of the tongue was $1.2 \mathrm{~cm}$. The length of the body was $1 \mathrm{~cm}$ whereas of the root $2 \mathrm{~mm}$. The anterior dorsal surface showed a relatively smooth surface lined by keratinized stratified squamous epithelium. Openings of lingual glands, partly filled with mucus were identified. The caudal part of the body of the tongue exhibited two slightly raised symmetrical areas. A transverse groove separated the root from the body of the tongue. Along the posterior border of the root, a crest of conical papillae was observed. Behind the glottis, big conical papillae were also recorded. Conclusion: These morphological findings could be useful for further studies of avian feeding mechanisms and comparisons with other avian species.
\end{abstract}

Keywords: avian, scanning electron microscopy, tongue.

\section{Introduction}

The avian tongue has been the subject of research by many authors. The great bulk of studies have been focused on the external morphology and on the dorsal lingual surface, by means of scanning electron microscopy (SEM) and secondarily by means of other histological techniques. The results of the morphological studies conducted so far, indicate a close correlation of the shape of the tongue with the method of food intake and the type of food and habitat.

The studies on the morphology of the tongue in the Galliformes are limited to the chicken (IWASAKI and KOBAYASHI, 1986; HOMBERGER and MEYERS, 1989), Chukar partridge (Alectoris chukar) (ERDOĞAN, SAĞSÖZ and AKBALIK, 2012), Common pheasant (Phasianus colchicus) (EMURA, 2008), Edward's pheasant (Lophura edwards) (EMURA, 2012), Red jungle fowl (Gallus gallus) (KADHIM, ZUKI, BABJEE et al., 2011), and Common quail (Coturnix coturnix) (PARCHAMI, FATAHIAN DEHKORDI and BAHADORAN, 2010). All of them belong to the Phasianidae family.

The quail (Coturnix coturnix japonica) represents an avian species, which is part of the wild fauna and a domestic animal as well. In addition, the quail is widely used in experimental biomedical research. It belongs to the order of Galliformes and it is a member of the Phasianidae family. For these reasons, it is important to assemble a database of the anatomical characteristics of this bird and its family. An attempt to describe the external lingual morphology of the common quail (Coturnix coturnix) has been made by Parchami, Fatahian Dehkordi and Bahadoran et al. (2010). However, some morphological features such as the openings of the lingual glands, the morphometry of the giant conical papillae, the fine appearance of the lingual epithelium, have not been explored. In addition, the Japanese quail is considered to be a separate species from the common quail (AINSWORTH, STANLEY and EVANS, 2010).

The aim of the present study was to analyze the threedimensional features of the lingual surface of the quail by scanning electron microscopy to elucidate the relationships, between the lingual morphology and the quail's feeding mechanisms. Additionally, possible similarities or differences among the members of Phasianidae will be discussed.

\section{Materials and Methods}

For this study, the tongues of six adult quails (Coturnix coturnix japonica) were used. After euthanasia of the birds (three males, three females), the tongues were removed, fixed in a sodium cacodylate buffered solution of $2 \%$ glutaraldehyde and 2\% paraformaldehyde and observed with the aid of stereomicroscopy. Pieces of the tongues were washed four times, for 15 min each time, with sodium cacodylate buffer ( $\mathrm{pH} 7.2$ ), transferred for 1 h to $1 \% \mathrm{OsO}_{4}$, and dehydrated in graded acetone. Tissues were critical point-dried in carbon dioxide (72-75 Barr), mounted onto stubs, and sputter coated with palladium and gold in a BalTec sputter coater. Specimens were observed in a JEOL, JSM 840 scanning electron microscope.

\section{Results}

Macroscopically, three parts may be distinguished namely the apex, the body and the root of the tongue. The tongue of the quail had triangular shape with a slightly rounded apex (Figure 1). The average length of the tongue was $1.2 \mathrm{~cm}$. The average length of the body was $1 \mathrm{~cm}$ whereas, that of 
the root $2 \mathrm{~mm}$. Dorsally, the tongue was divided into an anterior region five-sixths the length of the tongue and a posterior region one-sixth its length, the two regions being separated by a transverse row of giant conical papillae (Figure 1). A median shallow groove divided the anterior region into symmetrical halves. Ventrally, the anterior region of the tongue was coated with the lingual nail, or thickly keratinized epithelium.

The caudal part of the body of the tongue exhibited two slightly raised symmetrical areas. These areas are the wings of the tongue (Figure 2). A transverse groove separated the root from the body of the tongue (Figure 2). Along the posterior border of the root, a crest of conical papillae was observed. This crest had a main row of 24-26 papillae. Their height ranged from $0.2 \mathrm{~mm}$ to $0.5 \mathrm{~mm}$. At the edges of this row, bilaterally and ventrally two groups of $2-3$ papillae with a height $0.7-0.8 \mathrm{~mm}$ were prominent (Figure 2 ). All the papillae had a caudal direction and few of them were bifurcated. On their surface small papillae were recorded (Figure 3 ). These minuscule papillae had a length of $100-150 \mu \mathrm{m}$ and a width

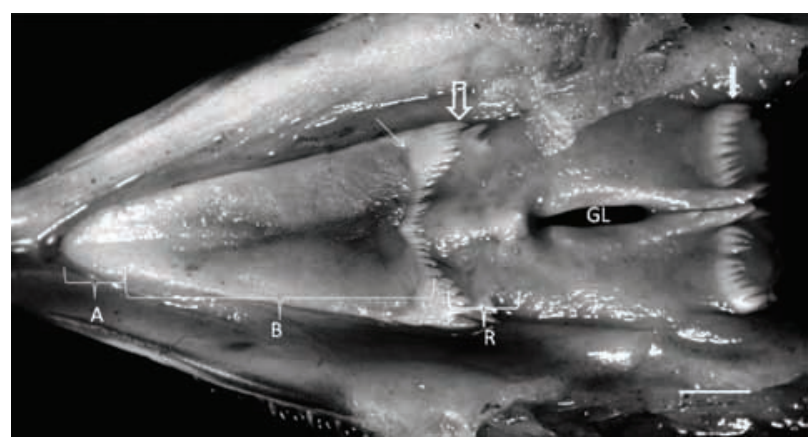

Figure 1. Photograph of the dorsal surface of the tongue of the quail. A, apex; B, body; R, root; GL, glottis; thin arrow, transverse sulcus; open arrow, row of conical papillae of the tongue ; black arrow, row of conical papillae. The scale bars equals to $2 \mathrm{~mm}$

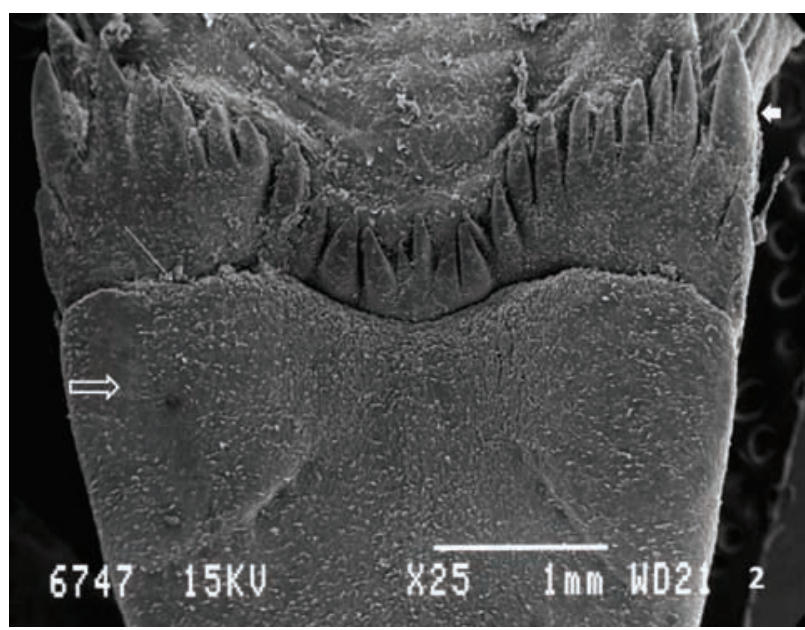

Figure 2. SEM photograph of the posterior portion of the body and the radix of the tongue. Open arrow, wing of the tongue; thin arrow, transverse sulcus; white arrow, giant conical papilla. of $60-70 \mu \mathrm{m}$ (Figure 4). Giant conical papillae almost like those between the anterior and the posterior regions were located behind the pharyngeal opening. They formed two rows. The upper-anterior composed of 22-24 whereas, the lower-posterior of two groups of 12 papillae (Figure 1).

On the dorso-lateral surface of the tongue, round openings of lingual glands, partly filled with mucus were identified (Figure 5). Their openings were round and slightly depressed in respect to the surrounding surface having an average diameter of 10-12 $\mu \mathrm{m}$ (Figure 6). The surrounding epithelial cells exhibited prominent microridges on their surface (Figure 7).

In the quail's tongue, scanning electron microscopy has shown that the dorsal surface of the anterior portion of the tongue was relatively smooth. In contrary, on the dorsal surface of the posterior portion, between the wings, prominent protrusions of the deciduous epithelium were observed (Figure 8).

The dorsal surface of the lingual mucosa as well that of papillae in the quail was covered by the stratified squamus

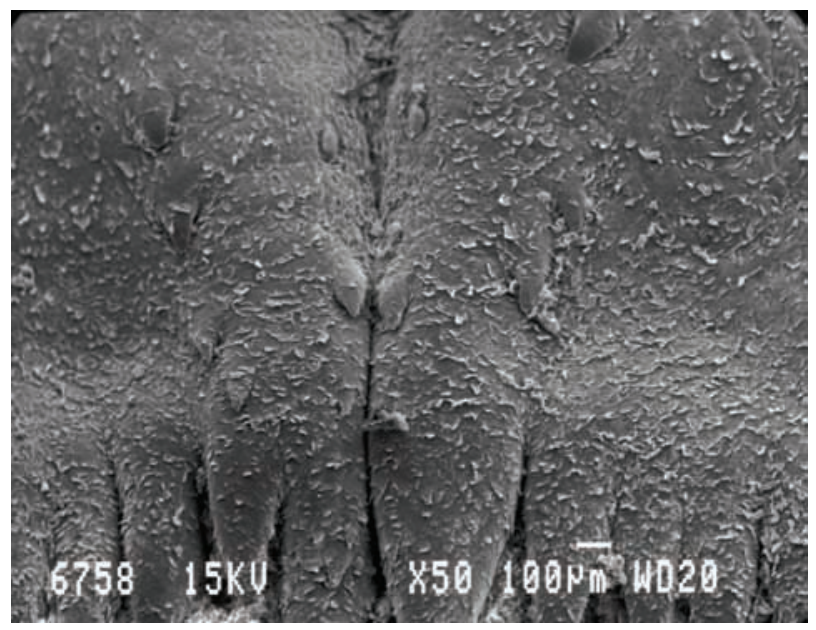

Figure 3. SEM photograph of a portion of the conical papillae. On their surface small papillae are prominent.

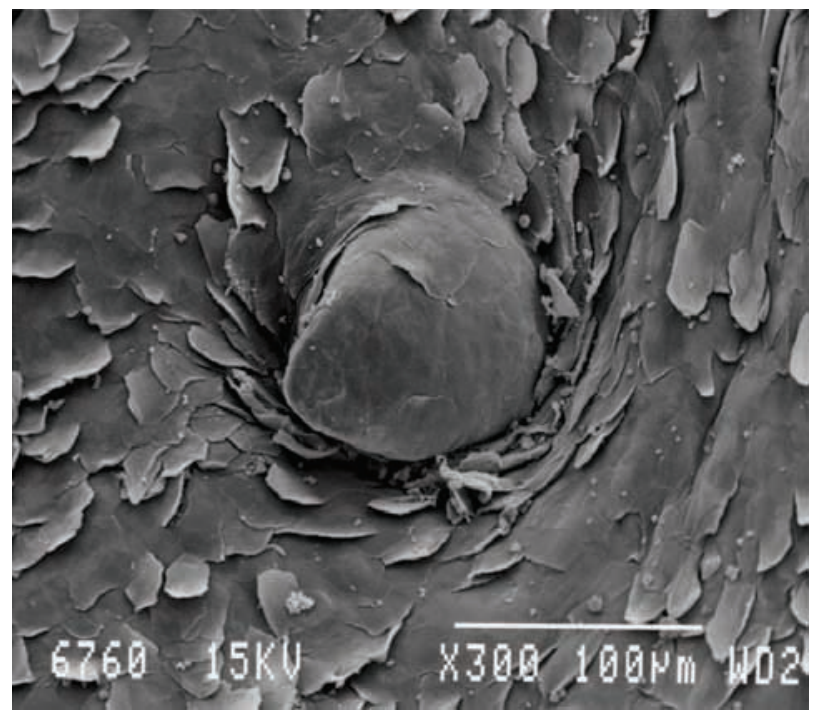

Figure 4. SEM photograph of a minuscule papilla. 


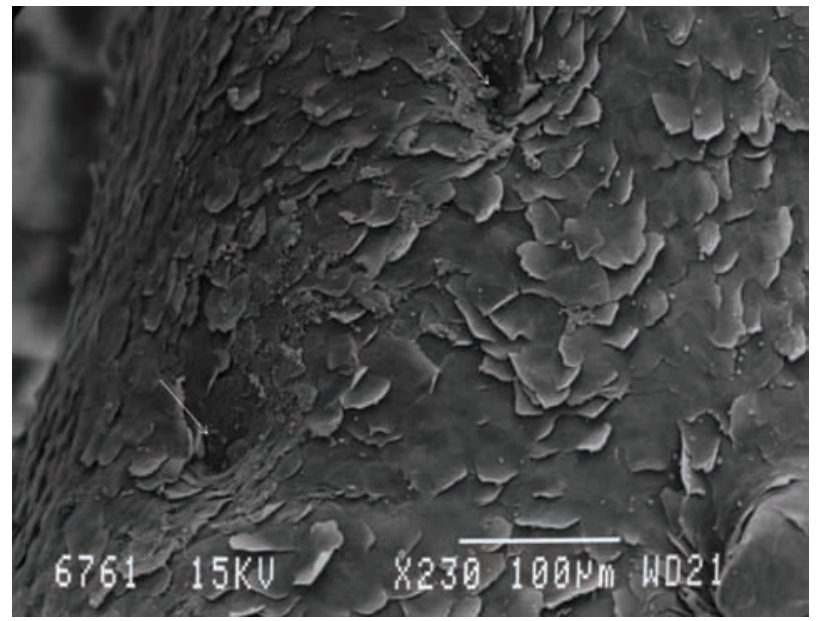

Figure 5. SEM photograph of the lingual surface. Arrows, openings of lingual glands. On the right, a small papilla is evident.

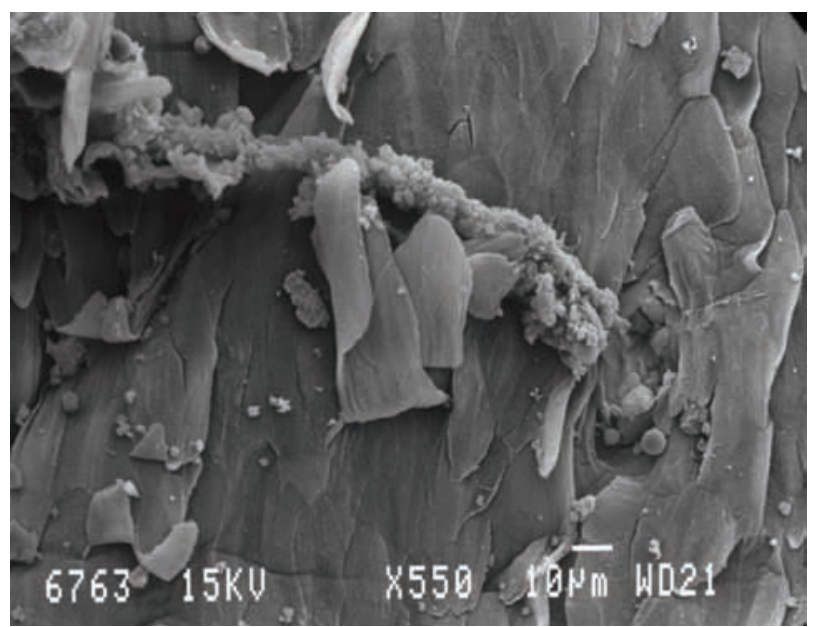

Figure 6. SEM photograph of the opening of a lingual gland with prominent extraction of mucus.

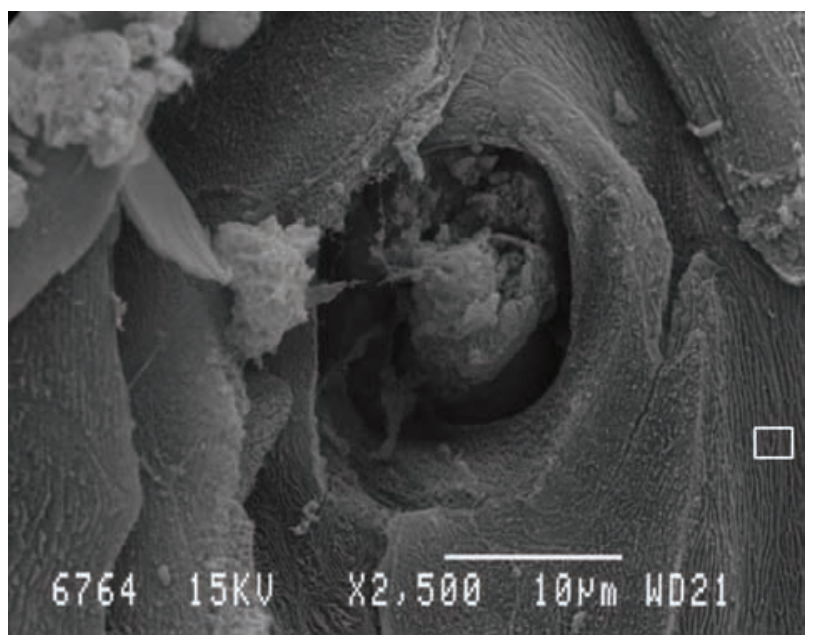

Figure 7. SEM photograph of the opening of a lingual gland. On the surface of the epithelial cells the dense network of microridges is evident. The inset is magnified in Figure 10.

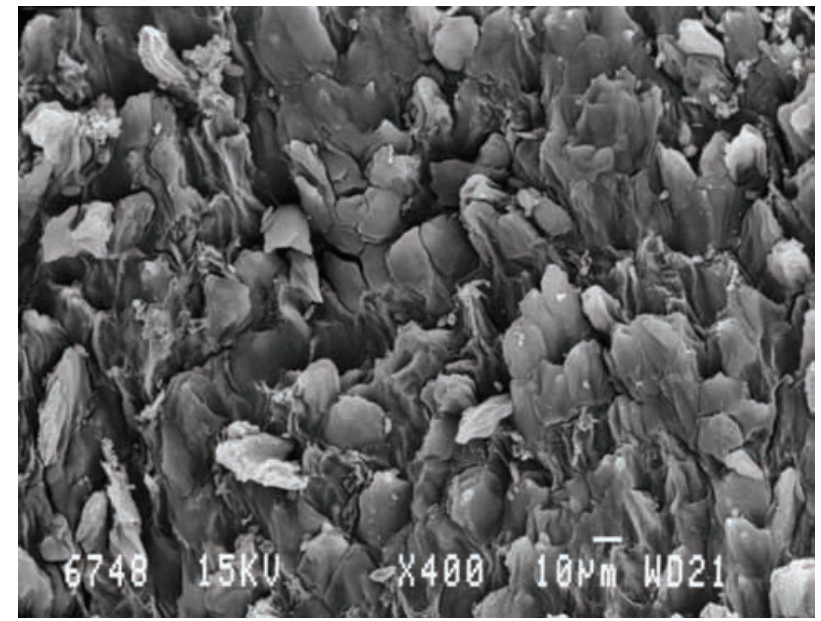

Figure 8. SEM photograph of the prominent protrusions of the deciduous epithelium on the surface of the posterior region of the tongue.

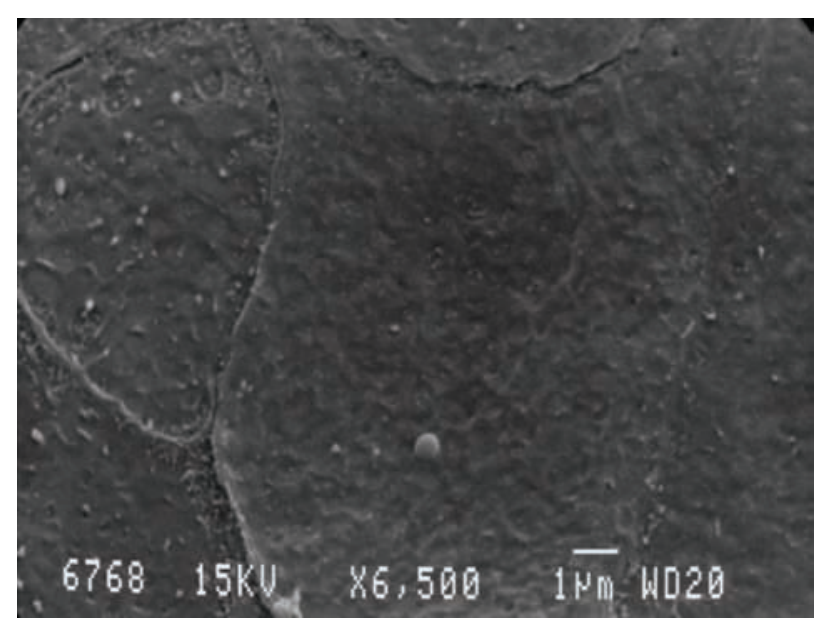

Figure 9. SEM photograph of epithelial cells with relative smooth surface.

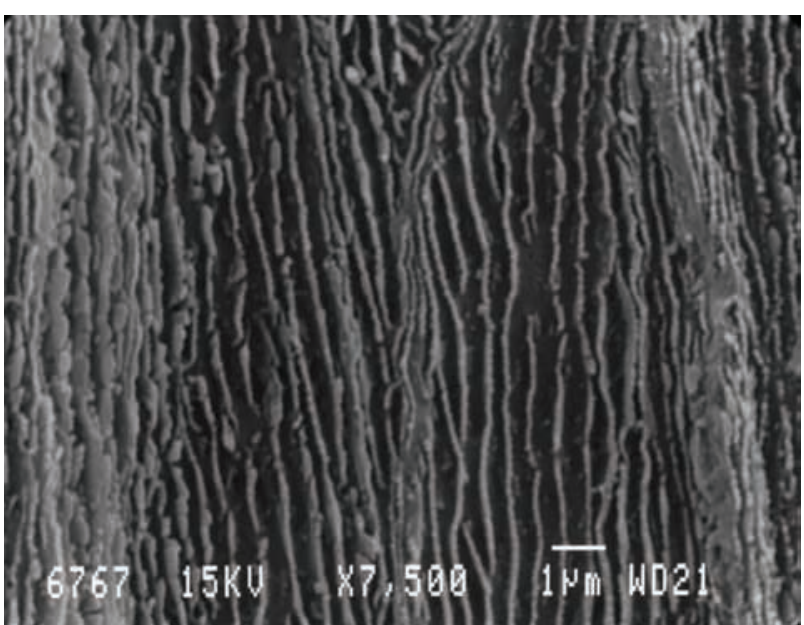

Figure 10. SEM magnification of the inset of Figure 7. The parallel rows of microridges on the surface of epithelial cells. 
epithelium. The outline of each cell in dorsal view was polygonal. The margins of cells were slightly thickened, and furrows were clearly visible between adjacent cells. Slight-elevated microridges adorned the surfaces of the cells (Figure 9). In other sites, especially on the lateral sides of the tongue, the surface of the epithelial cells exhibited a well developed network of microridges. These microridges formed parallel rows on the cellular surface (Figure 10).

\section{Conclusion}

The previous studies on the Phasianidae tongues provided only limited information on the surface features of this organ. The morphology of the chicken tongue serves as the pattern for further comparisons.

In the present study, the tongue appeared as an elongated triangle. Similar shape has been recorded in the tongues of the birds belonging to the Phasianidae. However, different dimensions have been recorded in the various members of the family.

The existence of the lingual wings has been recorded in the chicken (HOMBERGER and MEYERS, 1989) but, in the rest of the Galliformes has not been illustrated.

Big conical papillae were arranged on the dorsal surface between the lingual body and the lingual radix of the chicken (IWASAKI and KOBAYASHI, 1986), Red jungle fowl (KADHIM, ZUKI, BABJEE et al., 2011), Common pheasant (EMURA, 2008), Common quail (PARCHAMI, FATAHIAN DEHKORDI and BAHADORAN, 2010) in almost the same pattern. The big conical papillae seem to have a crucial role in the advancement of the swallowed food towards the esophagus and the preventing of its regurgitation.

In the chicken tongue, terminal modification of the dorsal epithelium was more distinctly different in the anterior and posterior regions. The so-called "filiform papillae" (IWASAKI and KOBAYASHI, 1986), or distinct protrusions of the deciduous epithelial cells were widely distributed over the anterior region of the chick tongue, whereas they were not present in the posterior region. In the present study these protrusions were more densely situated in the posterior region. These papillae were also illustrated in the common pheasant (EMURA, 2008) and in the common quail (PARCHAMI, FATAHIAN DEHKORDI and BAHADORAN, 2010).

Iwasaki and Kobayashi (1986) reported on the openings of lingual dorsal surface having diameter which ranged from 15 to $70 \mu \mathrm{m}$. Homberger and Meyers (1989) provided an extensive account on the salivary glands of the chicken without giving detailed information on their openings. The main function of the salivary glands is to produce the saliva, which plays a role in the moistening and lubrication of boli (GARGIULO, LORVIK, CECCARELLI et al., 1991; LIMAN, BAYRAM and KOÇAK, 2001) and particularly in the protection of the mucosal surface of the tongue against pathogenic micro-organisms, and in forming a hydrophilic environment on the tongue (GARGIULO, LORVIK, CECCARELLI et al., 1991).

Regarding the surface of the epithelial cells, two patterns have been detected. The cellular surfaces adorned with numerous microridges, were seen near the openings of the lingual glands. The presence of microridges could be associated with the friction, the adherence and spreading of mucus, the increase of the surface area, the maintaining of moisture on the free surface (CROLEY and SOLEY, 2010). Relative smooth cellular surfaces were seen mainly on and around the conical papillae. Variations of the surface of the epithelial lingual cells have also been observed, in the chicken (IWASAKI and KOBAYASHI, 1986). These variations probably represent adaptations of the tongue to the feeding mechanisms and to the environmental habitats (IWASAKI, 2002).

Food habits of phasianids are varied, consisting of a mixture of plant and animal material. Plant materials include: grains, seeds, roots, tubers, nuts, fruits, berries and foliage. Animal materials include: arthropods, mollusks, worms, lizards, and snakes (CAMPBELL and LACK, 1985).

In conclusion, the macroscopic as well as the scanning microscopic appearance of the tongue in the quail revealed the close affinity with that of the chicken. In view of the fact that chickens and quails feed in the same manner, the uneven surface of the lingual dorsum, coated with mucous fluid, seems to be suitable for intaking various foods. Apart from the microscopic appearance, the shape of the tongue plays a critical role in food movement within the buccal cavity during all feeding cycles. The fine structure of the cellular structures supports the feeding habits of this species. In fact, the surface morphology of the quail tongue supports the remarks of Zweers (1982) on the Galliformes feeding mechanism.

\section{References}

AINSWORTH, SJ., STANLEY, RL and EVANS, DJ. R. Developmental stages of the Japanese quail. Journal of Anatomy, 2010, vol.216,n. 1,p. 3-15. PMid:19929907 PMCid:PMC2807971. http://dx.doi.org/10.1111/j.1469-7580.2009.01173.x

CAMPBELL, B. and LACK, E. A Dictionary of birds. Vermilion: Buteo Books, 1985.

CROLEY, MR. and SOLEY, JT. Surface morphology of the emu (Dromaius novaehollandiae) tongue. Anatomia Histologia Embryologia, 2010, vol. 39, n. 4, p. 355-365. PMid:20491751. http://dx.doi.org/10.1111/j.1439-0264.2010.01002.x

EMURA, S. SEM studies on the lingual papillae and their connective tissue cores of the common pheasant (Phasianus colchicus). Medicine and Biology, 2008, vol. 152, n. 4, p. 129-133.

EMURA, S. SEM studies on the tongue of Edward's pheasant. Medicine and Biology, 2012, vol. 156, n. 11, p. 740-744.

ERDOĞAN, S., SAĞSÖZ, H. and AKBALIK, ME. Anatomical and histological structure of the tongue and histochemical characteristics of the lingual salivary glands in the Chukar partridge (Alectoris chukar, Gray 1830). British Poultry Science, 2012, vol. 53, n. 3, p. 307-315. PMid:22978586. http://dx.doi.org/10.1080/0007166 8.2012 .700507

GARGIULO, AM., LORVIK, S., CECCARELLI, P. and PEDINI, V. Histological and histochemical studies on the chicken lingual glands. British Poultry Science, 1991, vol. 32, n. 4, p. 693-702. PMid:1933443. http://dx.doi. org/10.1080/00071669108417395

HOMBERGER, DG. and MEYERS, R. Morphology of the lingual apparatus of the domestic chicken Gallus gallus, with special attention to the structure of the fasciae. American Journal of Anatomy, 1989, vol. 186, n. 3, p. 217-257. PMid:2618925. http://dx.doi.org/10.1002/aja.1001860302 
IWASAKI, S. Evolution of the structure and function of the vertebrate tongue. Journal of Anatomy, 2002, vol. 201, n. 1, p.1-13. PMid:12171472 PMCid:PMC1570891. http://dx.doi. org/10.1046/j.1469-7580.2002.00073.x

IWASAKI, S. and KOBAYASHI, K. Scanning and transmission electron microscopical studies on the lingual dorsal epithelium of chickens. Acta Anatomica Nipponica, 1986, vol. 61, n. 2, p. 83-96. PMid:3751494

KADHIM, KK., ZUKI, ABZ., BABJEE, SMA., NOORDIN, MM. and ZAMRI-SAAD, M. Morphological and histochemical observations of the red jungle fowl tongue Gallus gallus. African Journal of Biotechnology, 2011, vol. 10, n. 48, p. 9969-9977.

LIMAN, N., BAYRAM, G. and KOÇAK, M. Histological and histochemical studies on the lingual, preglottal and laryngeal salivary glands of the japanese quail (Coturnix coturnix japonica) at the post-hatching period. Anatomia Histologia Embryologia, 2001, vol. 30, n. 6, p. 367-373. PMid:11820407. http://dx.doi. org/10.1046/j.1439-0264.2001.00353.x

PARCHAMI, A., FATAHIAN DEHKORDI, RA. and BAHADORAN, S. Fine structure of the dorsal epithelium of the common quail (Coturnix coturnix). World Applied Sciences Journal, 2010, vol. 10, n. 10, p. 1185-1191.

ZWEERS, GA. Pecking of the pigeon (Columba livia L.). Behaviour, 1982, vol. 81, n. 2, p. 173-230. http://dx.doi. org/10.1163/156853982X00148

Received September 20, 2013 Accepted November 27, 2014 